\title{
Formação docente no contexto brasileiro das Instituições Federais de Educação Superior
}

\author{
Ailton Paulo de Oliveira Júnior a \\ Martha Maria Prata-Linhares ${ }^{b}$ \\ Acir Mário Karwoski c
}

\section{Resumo}

O objetivo do trabalho foi identificar quais ações são desenvolvidas pelas Instituições Federais de Educação Superior (IFES) no Brasil no que tange à formação docente para atuação na Educação Superior. Para tanto, foi aplicado por um grupo de trabalho no âmbito do Cograd um questionário junto às pró-reitorias de graduação que buscou identificar a existência de uma política institucional de formação continuada para seus docentes. Verifica-se uma tendência crescente de que a formação continuada é mais uma nova forma de regulação profissional do que promoção da profissionalização docente. São pontuados indicativos de ações de formação continuada, possíveis incentivos governamentais ou políticas públicas que possam impulsionar os programas de formação docente e que a realize interlocução com o governo federal, com as associações de professores, de técnicos-administrativos, de estudantes e com a sociedade em geral, indicando ações de uma política de formação docente.

Palavras-chave: Formação docente. Educação superior. Instituições federais. Brasil.

\section{Introdução}

No que se refere à formação e no desenvolvimento profissional do professor universitário, estudos de autores como André et al. (1999), Balzan (2000), Morosini (2001), Masetto (2002), Anastasiou (2002), Pimenta e Anastasiou (2005), Cunha e Zanchet (2010), dentre outros, sustentam a afirmativa da pouca atenção dada a este segmento de ensino no Brasil.

\footnotetext{
a Universidade Federal do ABC. Santo André, São Paulo, Brasil.

b Universidade Federal do Triângulo Mineiro. Uberaba, Minas Gerais, Brasil.

c Universidade Federal do Triângulo Mineiro. Uberaba, Minas Gerais, Brasil. 
O conceito de Desenvolvimento Profissional Docente (DPD) surgiu na literatura educacional para demarcar uma diferenciação com o processo tradicional e não contínuo de formação docente (PONTE, 1998).

Segundo Fiorentini e Crecci (2013), o termo "forma-ação" profissional denota uma ação de formar ou de dar forma a algo ou a alguém. Indaga também se essa ação de formar, sobretudo, inicialmente, tende a ser um movimento de "fora para dentro". O formador exerce uma ação que supõe necessária para que o aluno adquira uma forma esperada pelas instituições ou pela sociedade, para atuar em um campo profissional. Por isso, o termo "formação" muitas vezes tem sido associado a cursos, oficinas e treinamentos.

Ainda Fiorentini e Crecci (2013) dizem que:

O DPD remete também ao processo ou movimento de transformação dos sujeitos dentro de um campo profissional específico. Nesse sentido, o termo desenvolvimento profissional (DP) tende a ser associado ao processo de constituição do sujeito, dentro de um campo específico. Um processo, portanto, de vir a ser, de transformar-se ao longo do tempo ou a partir de uma ação formativa (p. 1).

Larrosa (1999) concebe a formação como uma ação de "dentro para fora", uma ação protagonizada pelo próprio sujeito sobre si, para que venha a adquirir uma forma projetada pelo próprio sujeito da formação, tendo em vista seus desejos e projetos de vida.

Almeida (2000, p. 2), ao buscar compreender a atividade docente e propor alternativas à preparação dos seus profissionais, aponta para a inseparabilidade entre formação e o conjunto das questões que, historicamente, têm permeado o seu fazer educativo: salário, jornada, carreira, condições de trabalho, currículo, gestão etc.

Sowder (2007), em vasta revisão bibliográfica, sintetiza que as perspectivas bem-sucedidas de desenvolvimento profissional de professores de matemática compreendem: a participação dos professores para decidir aspectos sobre a intervenção pedagógica; o apoio das várias partes interessadas; o envolvimento na resolução colaborativa de problemas ao longo do tempo; a avaliação formativa e a adequada instrução.

Nessa mesma perspectiva, Darling-Hammond et al. (2009) destacam que as práticas eficazes de desenvolvimento profissional: (a) ocorrem de modo intensivo e contínuo; 
(b) são conectadas às práticas docentes; (c) têm foco de atenção incidindo sobre a aprendizagem dos alunos; (d) são planejadas para atender aos conteúdos curriculares específicos; (e) são alinhadas às prioridades e às metas de melhoria do ensino; (f) são projetadas para construir relações fortes entre os professores.

Por outro lado, Sowder (2007), ao discutir o significado genérico de DPD, apoia-se nos estudos de Loucks-Horsley para apontar, entre outras coisas, que o termo pode significar em determinados contextos: (a) implementação de currículo; (b) seleção de materiais didáticos; (c) participação em redes de profissionais ou grupos de estudo; (d) pesquisa-ação; (e) estudos de caso; (f) participação em oficinas e seminários etc.

Morosini (2001), ao analisar a legislação de Educação Superior, apresenta limites quanto à formação didática do professor, constituindo-se, este, num campo de silêncio, ou seja, num tema não abordado. Na lei há a explicitação, apenas, de que o docente da Educação Superior deve ter competência técnica, mas não há uma definição consistente dos sentidos inerentes à expressão.

Gaeta e Prata-Linhares (2013) chamam a atenção para o aumento, durante os anos de 2003 a 2010, na oferta de cursos e vagas na Educação Superior, e para a necessidade de professores qualificados que irão atender a essa nova demanda. Salientam que não é somente uma demanda quantitativa, mas também qualitativa, pois o processo de ensino e aprendizagem torna-se cada vez mais complexo e se apresenta cada vez mais diverso, aspectos a que muitos professores não estão habituados.

Dalberio e Oliveira Júnior (2011) destacam que ser professor é uma tarefa que pressupõe alguns requisitos necessários: estar preparado teoricamente de maneira que esta teoria ilumine a sua prática pedagógica na interação com o aluno; saber fazer a ligação necessária do conteúdo teórico apreendido ou construído historicamente com a realidade vivencial do aluno, futuro profissional. Mas não basta apenas ter domínio da teoria e saber ser professor. É necessário que o professor universitário estabeleça um vínculo que ultrapasse os limites da relação pedagógica e alcance uma dimensão humana: pessoa a pessoa.

Segundo Campos (2011), as discussões sobre a importância e o significado da formação e do desenvolvimento profissional dos professores que atuam na Educação Superior nos últimos anos têm se destacado pela diversidade de concepções e enfoques presentes nas pesquisas e na literatura nacional e internacional. Esses estudos destacam sobremaneira a urgência de ressignificar os processos formativos a partir dos conhecimentos pedagógicos, inerentes e necessários à profissão docente. 
A docência na Educação Superior é uma atividade complexa e, por conseguinte, considera Cunha (2010):

[...] exige tanto uma preparação cuidadosa como singulares condições de exercício, o que pode distingui-la de outras profissões [...] o exercício da docência exige múltiplos saberes que precisam ser apropriados e compreendidos em suas relações. A ciência pedagógica situa-se nesse contexto e só com essa perspectiva contribui para a formação dos professores (p. 25-34).

A ampliação de nossas preocupações em compreender o processo formativo de docentes que atuam na Educação Superior decorre do reconhecimento de que educar nesses campos "[...] significa preparar os jovens para se elevarem ao nível da civilização atual, da riqueza de seus problemas, a fim de que aí atuem" (PIMENTA; ANASTASIOU, 2005, p. 81).

Paiva (2010, p. 170) afirma que os avanços da política pública de qualificação e formação docente, avaliação e coleta e tratamento de informações dos professores que atuam no magistério superior são aspectos da realidade brasileira que não podem ser descontinuados, e que a implantação de política pública, pautada em análises fidedignas da realidade, tem maior possibilidade de êxito.

É necessário investir na formação docente, principalmente na formação e inserção do jovem professor no campo educacional da docência. Cunha e Zanchet (2010, p. 196) enfatizam que esse investimento ultrapassa o interesse e o compromisso do campo da pedagogia e constitui, progressivamente, objeto do campo das políticas.

Segundo Demo (1997), ser professor é reconhecer a existência das práxis (teoria praticante - prática teorizante) e, em sua atuação, não há nada mais inovador do que repensar a própria ação, se compreendermos que inovar é um processo constante de reconstrução e, para tanto, é preciso repensar a prática realizando um processo dialético transformador. Rios (2002) completa dizendo que ir à busca do que é inovador não é apenas novidade, mas original, ou seja, deve-se ir à busca de algo nas suas origens, referindo-se ao que é provocador, estimulador para ir adiante e organizar de forma diferente o trabalho docente.

Há algum tempo, universidades estrangeiras mostram preocupação com a formação de seus professores criando centros para o desenvolvimento profissional de seus docentes. As denominações desses centros passam por nomes como "Centro 
de Ensino e Aprendizagem", como os da Universidade Católica Australiana e da Universidade de Saint Joseph nos Estados Unidos da América, ou "Centro de Aprendizagem e Ensino" como na Universidade de Glasgow na Escócia, na Universidade Sultan Qaboos em Oman, na Universidade da Tasmânia na Austrália e na Universidade de West Indies na Jamaica (NEISLER, 2015).

Esses são apenas alguns exemplos de uma prática institucionalizada em universidades sediadas em diversos países e que têm, em comum, a preocupação com a formação do docente universitário na relação com a aprendizagem de seus alunos.

Portanto, neste trabalho pretendemos identificar quais ações são desenvolvidas pelas Instituições Federais de Ensino Superior (IFES) no Brasil, no que tange à formação docente para atuação na Educação Superior, buscando identificar a existência de uma política institucional de formação continuada para os docentes nas IFES.

A partir desse estudo pretendemos identificar os tipos de concepções e de estilos de formação desenvolvidos pelas IFES, lançando ainda uma expectativa, em relação à problemática que será analisada.

\section{Procedimentos metodológicos}

Participaram da pesquisa 36 (69,23\%) IFES dentre um total de 52 que participaram do Colégio de Pró-Reitores de Graduação (Cograd), das universidades federais durante o ano de 2014.

Com o objetivo de identificar quais são as ações desenvolvidas pelas IFES, no que tange à formação docente para a Educação Superior, foi aplicado um instrumento - Anexo I - (questionário de perguntas abertas e fechadas) para a coleta das seguintes informações:

1. Existência, ou não, de uma política institucional de formação continuada para os docentes nas IFES.

2. Existência, ou não, de recurso orçamentário destinado à política institucional de formação continuada nas IFES.

3. Existência, ou não, de incentivo institucional para que o docente participe da formação continuada nas IFES. 
4. Existência, ou não, de mecanismos de avaliação da política de formação continuada na IFES.

5. Existência, ou não, de formas de socialização das experiências formativas na sua IFES.

6. Havendo uma política institucional de formação continuada na IFES, ou caso haja uma proposta, qual é o público-alvo, definição das temáticas e periodicidade para as atividades de formação?

7. Havendo uma política institucional de formação continuada na IFES, ou caso haja uma proposta, como são descrição da natureza, ações e respectivas cargas horárias das atividades formativas?

8. Havendo uma política institucional de formação continuada na IFES, ou caso haja uma proposta, descrever as dificuldades enfrentadas.

9. Havendo uma política institucional de formação continuada na IFES, ou caso haja uma proposta, as informações institucionais (relatórios, CPA etc.) são, ou não, utilizadas na definição da política de formação continuada?

10. Sugestões das IFES para apresentação de proposta de política de formação continuada dos docentes.

Portanto, neste trabalho realizou-se uma investigação sobre a formação continuada e o atual contexto de ampliação e responsabilização no trabalho docente em Instituições Federais de Ensino Superior no Brasil.

Para o estudo das questões do questionário, foi utilizada uma metodologia que é classificada como descritivo-transversal (realizado em determinado momento, sem que haja segmento posterior) com abordagem quantitativo-qualitativa.

\section{Resultados}

Tendo em vista a Tabela 1, a discussão dos dados considerou os seguintes agrupamentos:

1. Instituições que declararam ter uma política institucional de formação continuada para os docentes. 
2. Instituições que declararam NÃO TER uma política institucional de formação continuada para os docentes, mas que JÁ POSSUEM estratégias para a sua implantação.

3. Instituições que declararam NÃO TER uma política institucional de formação continuada para os docentes, e que NÃO POSSUEM estratégias para a sua implantação.

O número de instituições que têm uma política institucional de formação de professores converge para as conclusões de Fullan e Hargreaves (2000) ao afirmarem que tem sido exigido da universidade uma mudança/inovação quanto ao seu papel, qual seja, a de uma instituição organizacional aprendente, entendida como um terreno fértil às colaborações efetivas e à qualificação não somente daqueles que nela estudam, mas também para os que nela ensinam.

Dentre os 23 pró-reitores que representam suas IFES e que declararam que existe uma política institucional de formação continuada para os docentes, foi indagado sobre o tempo de existência dessa política. A Tabela 2 e a Tabela 2.1 apresentam estatísticas quanto à descrição do tempo dessa implantação.

Tabela 1. Declaração quanto à existência de uma política institucional de formação continuada para os docentes das IFES que participaram do Cograd em 2014.

\begin{tabular}{lcc}
\hline Existe política institucional & Número de IFES & Percentual \\
\hline Sim & 23 & $63,89 \%$ \\
Não (com estratégias) & 8 & $22,22 \%$ \\
Não (sem estratégias) & 5 & $13,89 \%$ \\
Total & $\mathbf{3 6}$ & $\mathbf{1 0 0} \%$ \\
\hline
\end{tabular}

Fonte: Elaborada pelos autores (2016).

Tabela 2. Distribuição do tempo da existência de uma política institucional de formação continuada para os docentes das IFES que participaram do Cograd em 2014.

\begin{tabular}{lcc}
\hline Tempo (anos) & Número de IFES & Percentual \\
\hline 0 a 2,5 & 5 & $26,32 \%$ \\
2,5 a 5 & 4 & $21,05 \%$ \\
5 a 7,5 & 5 & $26,32 \%$ \\
7,5 a 10 & 2 & $10,53 \%$ \\
10 a 12,5 & 2 & $10,53 \%$ \\
12,5 a 15 & - & $0 \%$ \\
15 a 17,5 & 1 & $5,26 \%$ \\
Total & $\mathbf{1 9}$ & $\mathbf{1 0 0} \%$ \\
\hline
\end{tabular}

Fonte: Elaborada pelos autores (2016). 
Tabela 2.1. Estatísticas do tempo da existência de uma política institucional de formação continuada para os docentes das IFES que participaram do Cograd em 2014.

\begin{tabular}{lc}
\hline Média & $\mathbf{5 , 3 4}$ anos \\
\hline Desvio-padrão & 4,12 anos \\
Coeficiente de variação & 0,7718 ou $77,18 \%$ \\
Mediana & 5 anos \\
Moda & 1 ano \\
Maior tempo & 17 anos \\
Menos tempo & 1 ano \\
\hline
\end{tabular}

Fonte: Elaborada pelos autores (2016).

Cabe destacar que das 23 IFES, 82,16\% declararam o tempo de existência da política institucional.

Nas Tabelas 2 e 2.1, observa-se que aproximadamente 50\% das IFES têm cinco anos ou menos de uma política institucional de formação continuada para os docentes, corroborado pelo valor da mediana. O coeficiente de variação $(0,7718)$ determina que os tempos de duração da política se mostram dispersos, o que ainda pode ser observado quanto ao maior tempo (17 anos) e quanto ao menor tempo (1 ano).

Quanto às instituições que declararam não ter uma política institucional de formação continuada para os docentes, mas que já possuem estratégias para a sua implantação, listamos a seguir as estratégias que pretendem implantar:

Criar cursos anuais de formação pedagógica; realização de oficinas e seminários; não existe uma política institucionalizada, o processo ocorre anualmente por meio de oficinas e um seminário (IFES 1). Instituir um programa o mais rápido possível (IFES 12).

Criação do comitê gestor de apoio à formação dos profissionais do magistério da Educação Básica. Adesão ao RENAFOR. Inserção no SINAFOR (IFES 19).

Há ações isoladas e pontuais que deverão ser institucionalizadas futuramente (IFES 20).

Pretende-se organizar as ações esparsas e desconexas em um Programa de Formação Continuada para os docentes, novos e ingressantes na carreira (IFES 26).

Pretende-se consolidar o PROFOR - Programa Permanente de Formação Docente a ser desenvolvido pelo NuDe - Núcleo de Desenvolvimento Educacional, órgão ligado à Pró-Reitoria de 
Ensino (Proens). Para implementação do PROFOR, são necessários recursos financeiros e humanos que até então não estão disponíveis na instituição (IFES 27).

Estamos em fase de elaboração (IFES 32).

Implantá-la a partir do próximo ano, como apoio da Secretaria de Gestão de Pessoas e Coordenação Pedagógica (IFES 34).

Das cinco IFES que declararam não ter uma política institucional de formação continuada para os docentes, e que não possuem estratégias para a sua implantação, três indicaram alguns pequenos posicionamentos que seguem, e as demais deixaram o questionário "em branco":

Há apenas o apoio para que os docentes façam MestradoDoutorado, por meio de convênios, etc. (IFES 2).

Constituímos um GT que está elaborando uma proposta para ser institucionalizada (IFES 11).

Criar institucionalmente essa política. A IFES é relativamente nova (IFES 24).

\subsection{Público alvo da política institucional de formação continuada para os docentes das IFES}

A Tabela 3 apresenta o público-alvo a que se destina a formação continuada nas IFES participantes desta pesquisa. Destaca-se o percentual de $43,48 \%$ das IFES que consideram que todos os professores da instituição façam parte do programa, quais sejam:

1. Docentes em estágio probatório que, após provimento efetivo, passam por um processo de avaliação no cargo. Nesse período, são verificadas se as características do candidato se adaptam ao cargo, além de outros atributos, como assiduidade, pontualidade, responsabilidade, iniciativa, entre outros.

2. Docentes efetivos que, após passarem do estágio probatório, conseguem a estabilidade no emprego, não podendo ser exonerado, salvo por ato infracionário grave.

3. Docentes substitutos que são contratados para suprir a falta de professor efetivo (vacância do cargo, afastamento/licença, nomeação para reitor, vice-reitor, diretor etc.), ou seja, para sua contratação é necessário que haja um código de vaga docente correspondente à vacância ou afastamento. 
4. Docentes temporários que são contratados para suprir as demandas decorrentes do Programa de Apoio a Planos de Reestruturação e Expansão das Universidades Federais (Reuni). Não há necessidade de haver código de vaga disponível; o/a professor/a entra em um código de vaga "fantasma".

Outras 43,48\% das IFES concentram-se em pensar uma política somente para os docentes efetivos, independentemente do tempo de serviço (com ou sem terem cumprido o tempo do estágio probatório).

A "IFES 3" descreve procedimento utilizado na avaliação dos docentes em seu programa, que pode servir como elemento norteador na elaboração de uma política nacional, qual seja:

Tabela 3. Público-alvo da política institucional de formação continuada, quando se aplica, para os docentes das IFES que participaram do Cograd em 2014.

\begin{tabular}{lcc}
\hline Público & $\begin{array}{c}\text { Número de } \\
\text { IFES }\end{array}$ & Percentual \\
\hline Docentes em estágio probatório, docentes efetivos e & 10 & $43,48 \%$ \\
docentes substitutos/temporários & 7 & $30,43 \%$ \\
Docentes em estágio probatório e docentes efetivos & 3 & $13,04 \%$ \\
Docentes efetivos, independente do tempo de serviço & 2 & $\mathbf{8 , 7 0 \%}$ \\
Docentes em estágio probatório & 1 & $\mathbf{4 , 3 5 \%}$ \\
Docentes efetivos e docentes substitutosttemporários & $\mathbf{2 3}$ & $\mathbf{1 0 0 \%}$ \\
Total &
\end{tabular}

Fonte: Elaborada pelos autores (2016).

Tabela 3.1. Público-alvo da política institucional de formação continuada para os docentes das IFES que participaram do Cograd em 2014, que não a aplicaram, mas possuem estratégias.

\begin{tabular}{lcc}
\hline Público & $\begin{array}{c}\text { Número de } \\
\text { IFES }\end{array}$ & Percentual \\
\hline Docentes em estágio probatório e docentes efetivos & 2 & $25,00 \%$ \\
Docentes efetivos, independente do tempo de serviço & 2 & $25,00 \%$ \\
Docentes em estágio probatório & 1 & $12,50 \%$ \\
Docentes substitutosłtemporários & 1 & $12,50 \%$ \\
Não responderam & 2 & $25,00 \%$ \\
Total & $\mathbf{8}$ & $\mathbf{1 0 0} \%$ \\
\hline
\end{tabular}

Fonte: Elaborada pelos autores (2016). 


\begin{abstract}
A partir da vigência da Resolução que instituiu o programa de formação continuada na IFES, todos os docentes da Universidade frequentarão, ao longo do período probatório, atividades no âmbito do Programa. Os docentes aos quais for atribuída média inferior a 6,0 pontos na segunda avaliação docente pelo discente e consecutiva serão orientados na esfera do departamento a que pertencem e encaminhados à Prograd, a fim de frequentarem atividades no âmbito do Programa de Formação Continuada (IFES 3).
\end{abstract}

Considerando as instituições que ainda não têm uma política institucional de formação continuada, Tabela 3.1, mas que apresentam algumas estratégias para a sua implantação, observa-se que metade dessas IFES pensa uma política para os docentes efetivos, independente do tempo de serviço (com ou sem terem cumprido o tempo do estágio probatório). Cabe ainda destacar que duas delas $(25,00 \%)$ não declararam a quem se destina a política de formação continuada.

\title{
3.2 Órgão(s) responsável(is) pela execução da política institucional de formação continuada para os docentes das IFES
}

Observa-se na Tabela 4 que a maioria das IFES, 73,91\%, responsabiliza a administração superior da instituição como órgão pela execução da política de formação continuada. Ainda 21,74\% das IFES dividem esta responsabilidade entre a administração superior e as unidades acadêmicas que estão mais próximas aos docentes e às suas necessidades.

Acompanhando as IFES que já têm implantada essa política, na Tabela 4.1, observa-se que também a maioria das IFES, 75,00\%, responsabilizaria a administração superior da instituição como órgão pela execução da política de

Tabela 4. Órgão(s) responsável(is) pela execução da política institucional de formação continuada para os docentes das IFES que participaram do Cograd em 2014.

\begin{tabular}{lcc}
\hline Órgão & $\begin{array}{c}\text { Número de } \\
\text { IFES }\end{array}$ & Percentual \\
\hline Administração superior & 17 & $73,91 \%$ \\
Administração superior e unidades acadêmicas & 5 & $21,74 \%$ \\
Unidades acadêmicas & 1 & $4,35 \%$ \\
Total & $\mathbf{2 3}$ & $\mathbf{1 0 0} \%$ \\
\hline
\end{tabular}

Fonte: Elaborada pelos autores (2016). 
Tabela 4.1. Órgão(s) responsável(is) pela execução da política institucional de formação continuada para os docentes das IFES que participaram do Cograd em 2014, que não a aplicaram, mas possuem estratégias.

\begin{tabular}{lcc}
\hline Órgão & Número de IFES & Percentual \\
\hline Administração superior & 6 & $75,00 \%$ \\
Unidades acadêmicas & 1 & $12,50 \%$ \\
Não respondeu & 1 & $12,50 \%$ \\
Total & $\mathbf{8}$ & $\mathbf{1 0 0 \%}$ \\
\hline
\end{tabular}

Fonte: Elaborada pelos autores (2016).

formação continuada. Não há um pensar em dividir essa responsabilidade com as unidades acadêmicas.

\subsection{Definição de periodicidade para as atividades de formação}

Na Tabela 5 observa-se que quase dois terços das IFES declaram que há a definição de uma periodicidade nas atividades de formação continuada. Cabe destacar que duas instituições não declararam se há, ou não, periodicidade em suas atividades.

A Tabela 5.1 mostra qual a periodicidade em que as instituições definem as atividades de formação continuada. Dessa forma, observa-se que quase $50,00 \%$ dessas o fazem anualmente. Outras, $40,00 \%$, o fazem semestralmente, parecendo indicar que acompanham os semestres letivos.

Na Tabela 5.2 observa-se que metade das IFES declara que há um pensar na definição de uma periodicidade nas atividades de formação continuada a serem implantadas na política institucional.

Quanto às IFES, que declararam não ter uma política institucional de formação continuada para os docentes, mas que já possuem estratégias para a sua implantação, somente duas delas declararam a periodicidade das atividades, ou seja, a política institucional ocorre semestral ou trimestralmente.

Tabela 5. Declaração quanto à definição de periodicidade para as atividades de formação das IFES que participaram do Cograd em 2014.

\begin{tabular}{lcc}
\hline Estabelecem periodicidade nas atividades de formação & Número de IFES & Percentual \\
\hline Sim & 15 & $65,21 \%$ \\
Não & 6 & $26,09 \%$ \\
Não declararam & 2 & $8,70 \%$ \\
Total & $\mathbf{2 3}$ & $\mathbf{1 0 0 \%}$ \\
\hline
\end{tabular}

Fonte: Elaborada pelos autores (2016). 
Tabela 5.1. Periodicidade em que são realizadas as atividades de formação das IFES que participaram do Cograd em 2014.

\begin{tabular}{lcc}
\hline Periodicidade & Número de IFES & Percentual \\
\hline Anualmente & 6 & $40,00 \%$ \\
Anualmente e em probatório após a posse & 1 & $6,67 \%$ \\
Semestralmente & 6 & $40,00 \%$ \\
Após professor tomar posse & 1 & $6,67 \%$ \\
Mínimo de uma vez por ano & 1 & $6,67 \%$ \\
Total & $\mathbf{1 5}$ & $\mathbf{1 0 0} \%$ \\
\hline
\end{tabular}

Fonte: Elaborada pelos autores (2016).

Tabela 5.2. Declaração quanto à definição de periodicidade para as atividades de formação das IFES que participaram do Cograd em 2014, que não a aplicaram, mas possuem estratégias.

\begin{tabular}{lcc}
\hline Estabelecem periodicidade nas atividades de formação & Número de IFES & Percentual \\
\hline Sim & 4 & $50,00 \%$ \\
Não & 4 & $50,00 \%$ \\
Total & $\mathbf{8}$ & $\mathbf{1 0 0 \%}$ \\
\hline
\end{tabular}

Fonte: Elaborada pelos autores (2016).

\subsection{Natureza das atividades formativas}

No tocante à natureza das atividades formativas, 43,48\% (Tabela 6) das IFES indicam que as atividades de formação continuada focam-se, principalmente, nos seguintes aspectos: (1) Formação (melhoria da prática pedagógica); (2) Desenvolvimento (favorecer o desenvolvimento profissional dos professores, contribuindo para uma consequente melhoria da prática pedagógica); (3) Atualização (relativa aos conhecimentos específicos).

Pimenta e Anastasiou (2005) nos alertam que nos processos de formação de professores é preciso considerar a importância dos saberes das áreas de conhecimento (ninguém ensina o que não sabe), dos saberes pedagógicos (pois o ensinar é uma prática educativa que tem diferentes e diversas direções de sentido na formação do humano), dos saberes didáticos (que tratam da articulação da teoria da Educação e da teoria de ensino para ensinar nas situações contextualizadas), dos saberes da experiência do sujeito professor (que dizem do modo como nos apropriamos do ser professor em nossa vida).

Outros aspectos foram citados como circulação de informações; produções científicas; troca de experiências; e compartilhamento de materiais de ensino.

Assim, percebe-se que não há uma convergência quanto à natureza das atividades. 
A Tabela 6.1 mostra que, dentre as IFES que ainda não têm uma política institucional para a formação continuada, não há uma convergência quanto à natureza das atividades. Observa-se que há, para cada uma delas, um diferente pensar em relação ao que focar na elaboração das atividades.

Tabela 6. Declaração quanto à natureza das atividades formativas das IFES que participaram do Cograd em 2014.

\begin{tabular}{lcc}
\hline Natureza das atividades formativas & Número de IFES & Percentual \\
\hline De formação, desenvolvimento, atualização e outros* & 6 & $26,09 \%$ \\
De formação, desenvolvimento e atualização & 4 & $17,39 \%$ \\
Somente de formação & 2 & $8,70 \%$ \\
De formação e outros* & 2 & $8,70 \%$ \\
Somente de desenvolvimento & 1 & $4,35 \%$ \\
De desenvolvimento e outros* & 1 & $4,35 \%$ \\
Somente de atualização & 1 & $4,35 \%$ \\
De atualização e outros* & 1 & $4,35 \%$ \\
De formação e desenvolvimento & 1 & $4,35 \%$ \\
De formação, desenvolvimento e outros* & 1 & $4,35 \%$ \\
De formação e atualização & 1 & $4,35 \%$ \\
De formação, atualização e outros* & 1 & $4,35 \%$ \\
Outros* & 1 & $4,35 \%$ \\
Total & $\mathbf{2 3}$ & $\mathbf{1 0 0} \%$ \\
\hline
\end{tabular}

* "Outros" corresponde a: circulação de informações, produções científicas, troca de experiências e compartilhamento de materiais de ensino.

Fonte: Elaborada pelos autores (2016).

Tabela 6.1. Declaração quanto à natureza das atividades formativas para as IFES que participaram do Cograd em 2014, que não a aplicaram, mas possuem estratégias.

\begin{tabular}{lcc}
\hline Natureza das atividades formativas & Número de IFES & Percentual \\
\hline Somente de formação & 1 & $12,50 \%$ \\
De desenvolvimento e outros* & 1 & $12,50 \%$ \\
De formação, desenvolvimento e outros* & 1 & $12,50 \%$ \\
De formação e atualização & 1 & $12,50 \%$ \\
De formação, atualização e outros* & 1 & $12,50 \%$ \\
Outros* $^{*}$ & 3 & $37,50 \%$ \\
Total & $\mathbf{8}$ & $\mathbf{1 0 0} \%$ \\
\hline
\end{tabular}

* "Outros" corresponde a: circulação de informações, produções científicas, troca de experiências e compartilhamento de materiais de ensino.

Fonte: Elaborada pelos autores (2016). 


\subsection{Ações oferecidas pelas IFES}

Quando consideradas as ações oferecidas pelas IFES em suas atividades de formação continuada, não é observada uma ação convergente entre as instituições participantes do estudo, Tabela 7. Dentre as opções do instrumento de pesquisa, temos que 39,11\% das IFES declaram utilizar as seguintes ações: cursos; oficinas; seminários; dentre outras ações.

Dessa forma, cabe aqui destacar alguns elementos que diferenciem possíveis ações para a implantação de uma política institucional de âmbito nacional no tocante às instituições federais, quais sejam:

1. Cursos - consiste no detalhamento de determinado assunto ou conjunto de temas com o foco em "treinar" ou "ensinar a fazer". É composto de exposições de pessoas normalmente com formação acadêmica que procuram passar seu conhecimento aos participantes ${ }^{1}$;

2. Oficina - reunião de trabalho envolvendo vários profissionais para a discussão de determinado assunto ou para o desenvolvimento de determinada técnica ${ }^{2}$;

Tabela 7. Declaração quanto às ações de formação continuada oferecidas pelas IFES que participaram do Cograd em 2014.

\begin{tabular}{lcc}
\hline Ações & Número de IFES & Percentual \\
\hline Cursos, oficinas e seminários & 6 & $26,09 \%$ \\
Somente seminários & 6 & $26,09 \%$ \\
Cursos, oficinas, seminários e outros* $^{*}$ & 3 & $13,02 \%$ \\
Oficinas, seminários e outros* $^{*}$ & 2 & $8,70 \%$ \\
Oficinas e outros* $^{*}$ Cursos, oficinas e outros* $^{*}$ & 2 & $8,70 \%$ \\
Cursos e seminários $^{*}$ & 1 & $4,35 \%$ \\
Oficinas e seminários & 1 & $4,35 \%$ \\
Cursos e oficinas & 1 & $4,35 \%$ \\
Total & 1 & $4,35 \%$ \\
\hline
\end{tabular}

* Não foram especificados quais outros modelos seriam utilizados.

Fonte: Elaborada pelos autores (2016).

1 Ver: NEVES, N. Conheça as diferenças entre os tipos de eventos antes de iniciar a organização. Manager Online. Barueri, [s.d.]. Disponível em: <http://www.manager.com.br/reportagem/reportagem.php?id_ reportagem $=403>$. Acesso em: 11 nov. 2015.

2 Ver: ZANETTI, E. Workshops, oficinas, seminários e convenções qual a diferença? Blog do Eloi Zanetti. 25 jul. 2012. Disponível em <http://www.eloizanetti.com.br/blog/2012/07/workshops-oficinas-seminarios-econvencoes-qual-a-diferenca/>. Acesso em: 16 nov. 2015. 
3. Seminários - comuns no meio acadêmico, especialmente quando um especialista vem expor suas descobertas em seu campo de estudos ${ }^{3}$.

Também nas ações oferecidas pelas IFES que já pensam atividades de formação continuada não são observadas ações convergentes entre as instituições participantes do estudo, Tabela 7.1.

Tabela 7.1. Declaração quanto às ações oferecidas pelas IFES que participaram do Cograd em 2014, que não a aplicaram, mas possuem estratégias.

\begin{tabular}{lcc}
\hline Ações & Número de IFES & Percentual \\
\hline Cursos, oficinas e seminários & 2 & $25,00 \%$ \\
Somente cursos & 1 & $12,50 \%$ \\
Cursos, oficinas, seminários e outros* & 1 & $12,50 \%$ \\
Cursos e seminários & 1 & $12,50 \%$ \\
Oficinas e seminários & 1 & $12,50 \%$ \\
Não responderam & 2 & $25,00 \%$ \\
Total & $\mathbf{8}$ & $\mathbf{1 0 0} \%$ \\
\hline
\end{tabular}

* Não foram especificados quais outros modelos seriam utilizados.

Fonte: Elaborada pelos autores (2016).

\subsection{Recurso orçamentário destinado à política de formação continuada nas IFES}

Na Tabela 8 , observa-se que $43,48 \%$ das IFES, pouco menos da metade, declaram que não há recursos orçamentários destinados à política de formação continuada. Dessa forma, caberia identificar quais alternativas são utilizadas para a implantação da formação continuada dos docentes de cada uma dessas IFES.

Tabela 8. Declaração quanto à existência de recurso orçamentário destinado à política de formação continuada nas IFES que participaram do Cograd em 2014.

\begin{tabular}{lcc}
\hline Periodicidade atividades formação & Número de IFES & Percentual \\
\hline Sim & 13 & $56,52 \%$ \\
Não & 10 & $43,48 \%$ \\
Total & $\mathbf{2 3}$ & $\mathbf{1 0 0 \%}$ \\
\hline
\end{tabular}

Fonte: Elaborada pelos autores (2016).

3 Ver: Ibidem, 2015. 
Na Tabela 8.1, observa-se que duas IFES declaram que há indicativo de haver recurso orçamentário para a implantação de uma política institucional de formação continuada.

Tabela 8.1. Declaração quanto à existência de recurso orçamentário destinado à política de formação continuada nas IFES que participaram do Cograd em 2014, que não a aplicam, mas possuem estratégias.

\begin{tabular}{lcc}
\hline Existência de recurso orçamentário & Número de IFES & Percentual \\
\hline Sim & 2 & $25,00 \%$ \\
Não & 5 & $62,50 \%$ \\
Não respondeu & 1 & $12,50 \%$ \\
Total & $\mathbf{8}$ & $\mathbf{1 0 0} \%$ \\
\hline
\end{tabular}

Fonte: Elaborada pelos autores (2016).

A formação continuada para a atuação na Educação Superior tem que considerar um investimento intenso do professor em sua função, pois como reforça Day (2005) o processo é complexo, exigindo uma articulação entre saberes, questões curriculares e estratégias de ensino, interações interpessoais e de conhecimentos, além da motivação dos alunos para aprender.

\subsection{Existência de algum tipo de incentivo institucional para o docente que participa da formação continuada nas IFES}

Na Tabela 9, observa-se que $65,22 \%$ das IFES declaram que não há incentivo institucional para que o docente participe das atividades de formação continuada oferecidas. Não havendo incentivos, há real interesse dos docentes em participar dessa formação? E das IFES que apresentam elementos de incentivo à participação em atividades de formação continuada há interesse diferenciado.

Na Tabela 9.1, observa-se que somente 25,00\% das IFES declaram pensar em estabelecer estratégias de incentivo institucional para que o docente participe das atividades de formação continuada.

Tabela 9. Declaração quanto à existência de algum tipo de incentivo institucional para o docente que participa da formação continuada nas IFES que participaram do Cograd em 2014.

\begin{tabular}{lcc}
\hline Existência de incentivo institucional & Número de IFES & Percentual (\%) \\
\hline Sim & 8 & $34,78 \%$ \\
Não & 15 & $65,22 \%$ \\
Total & $\mathbf{2 3}$ & $\mathbf{1 0 0 \%}$ \\
\hline
\end{tabular}

Fonte: Elaborada pelos autores (2016). 
Tabela 9.1. Declaração quanto à existência de algum tipo de incentivo institucional para o docente que participa da formação continuada nas IFES que participaram do Cograd em 2014, que não a aplicaram, mas possuem estratégias.

\begin{tabular}{lcc}
\hline Existência de incentivo institucional & Número de IFES & Percentual (\%) \\
\hline Sim & 2 & $25,00 \%$ \\
Não & 6 & $75,00 \%$ \\
Total & $\mathbf{8}$ & $\mathbf{1 0 0 \%}$ \\
\hline
\end{tabular}

Fonte: Elaborada pelos autores (2016).

\subsection{Informações institucionais (relatórios, CPA etc.) utilizadas na definição de política de formação continuada nas IFES}

Na Tabela 10, observa-se que 86,96\% das IFES declaram que informações institucionais tais como relatórios de gestão, relatórios gerados pela Comissão Própria de Avaliação (CPA), conforme disposto na Lei nº 10.861 de 14/04/2004, do Sistema Nacional de Avaliação da Educação Superior (Sinaes) (BRASIL, 2004) e outros documentos são utilizados para a definição de política de formação continuada. Somente 13,04\% não utilizam informações institucionais para a definição de sua política.

Destacamos algumas declarações das IFES que esclarecem a utilização dos relatórios para definição de política de formação continuada, quais sejam:

O PROCAF toma como referências o Relatório de Avaliação Institucional do Docente pelo Discente, além disso, promove encontros com as Unidades Acadêmicas para levantar demandas de formação (IFES 3).

Relatório de avaliação interna e externa dos cursos de Graduação (IFES 7).

O Programa de Formação Docente se referencia no Sinaes para propor projetos e ações para a formação continuada (IFES 9).

Dados dos docentes/formaçãopedidos dos docentes." (IFES 14).

Os indicadores apontados como: número de retração e evasão dos cursos, a avaliação dos discentes sobre os projetos pedagógicos e metodologia docente, entre outros (IFES 16).

Foi realizado um levantamento, junto aos professores e estudantes de modo a oferecer subsídios e mapear as reais demandas da 
Universidade. As ações ainda são experimentais, estão em curso e pretendemos utilizar as diversas informações para a constituição do Programa de Ações formativas para a docência no-para o Ensino Superior em nossa instituição (IFES 17).

Os dados do ENADE, avaliação interna das disciplinas, demandas de colegiados nos permitem definir os temas e áreas que necessitam de maiores investimentos (IFES 18).

Além do relatório da CPA também são realizadas reuniões com as unidades acadêmicas e coordenações de curso, visando a identificar sugestões de temáticas a serem abordadas e discutidas durante as ações formativas do Programa (IFES 30).

Na Tabela 10.1 observa-se que somente $25,00 \%$ das IFES pensam utilizar informações institucionais para a definição de política de formação continuada.

Somente a IFES 33 declara que irá utilizar "relatórios com a avaliação dos eventos anteriores".

Tabela 10. Informações institucionais (relatórios, CPA etc.) que são utilizadas na definição de política de formação continuada, nas IFES que participaram do Cograd em 2014.

\begin{tabular}{lcc}
\hline Informações institucionais & Número de IFES & Percentual (\%) \\
\hline Sim & 20 & $86,96 \%$ \\
Não & 3 & $13,04 \%$ \\
Total & $\mathbf{2 3}$ & $\mathbf{1 0 0 \%}$ \\
\hline
\end{tabular}

Fonte: Elaborada pelos autores (2016).

Tabela 10.1. Informações institucionais (relatórios, CPA etc.) são utilizadas na definição de política de formação continuada nas IFES que participaram do Cograd em 2014, que não a aplicaram, mas possuem estratégias.

\begin{tabular}{lcc}
\hline Informações institucionais & Número de IFES & Percentual (\%) \\
\hline Sim & 2 & $25,00 \%$ \\
Não & 3 & $37,50 \%$ \\
Não responderam & 3 & $37,50 \%$ \\
Total & $\mathbf{8}$ & $\mathbf{1 0 0 \%}$ \\
\hline
\end{tabular}

Fonte: Elaborada pelos autores (2016). 


\subsection{Responsáveis pelas temáticas abordadas nas ações formativas das IFES}

Na Tabela 11, observa-se que a responsabilidade pelas temáticas abordadas nas ações formativas das IFES é, principalmente, uma conjunção entre os órgãos responsáveis pela execução da política e/ou sugestão dos professores em formação.

Algumas IFES ainda, em menor número, também conjugam ações das coordenações dos cursos e dos diversos departamentos, esferas estas representativas do corpo docente.

Em geral, o órgão responsável pela definição das temáticas é a Pró-Reitoria de Graduação, como vemos a seguir:

1. Pró-Reitoria de Graduação/Setor Pedagógico (IFES 3);

2. Progep e Prograd(IFES 7);

3. Pró-Reitoria de Graduação (IFES 9);

Tabela 11. Responsável pela definição das temáticas abordadas nas ações formativas das IFES que participaram do Cograd em 2014.

\begin{tabular}{lcc}
\hline Responsável pela definição das temáticas & $\begin{array}{c}\text { Número de } \\
\text { IFES }\end{array}$ & Percentual \\
\hline $\begin{array}{l}\text { Órgão responsável pela execução da política ou sugestão dos } \\
\text { professores em formação }\end{array}$ & 4 & $17,39 \%$ \\
$\begin{array}{l}\text { Órgão responsável pela execução da política } \\
\text { Órgão responsável pela execução da política; sugestão } \\
\text { dos professores em formação; ações das coordenações e } \\
\text { departamentos }\end{array}$ & 3 & $13,04 \%$ \\
$\begin{array}{l}\text { Órgão responsável pela execução da política; comitê assessor } \\
\text { específico; núcleos estruturantes; ou sugestão dos professores } \\
\text { em formação }\end{array}$ & 2 & $13,04 \%$ \\
$\begin{array}{l}\text { Órgão responsável pela execução da política; comitê assessor } \\
\text { específico; ou sugestão dos professores em formação }\end{array}$ & 2 & $8,70 \%$ \\
$\begin{array}{l}\text { Órgão responsável pela execução da política; núcleos } \\
\text { estruturantes; ou sugestão dos professores em formação }\end{array}$ & 2 & $8,70 \%$ \\
$\begin{array}{l}\text { Outros* } \\
\text { Total }\end{array}$ & 7 & $\mathbf{8 , 7 0 \%}$ \\
\hline
\end{tabular}

* Combinações com somente uma indicação.

Fonte: Elaborada pelos autores (2016). 
4. Coordenadoria ligada à Prograd (IFES 13);

5. Ciapes-Prograd (Coordenação de Inovação Acadêmica e Pedagógica no Ensino Superior) (IFES 17);

6. Proeg;

7. PREG/CAAP;

8. A Pró-Reitoria de Graduação possui uma equipe de apoio pedagógico que trabalha na organização e execução das atividades do Programa de Formação Docente (IFES 30).

Na Tabela 11.1, observa-se também que a responsabilidade pelas temáticas abordadas nas ações formativas das IFES que somente têm o pensar sobre uma política de formação de professores é, principalmente, uma conjunção entre os órgãos responsáveis pela execução da política e/ou sugestão dos professores em formação.

\subsection{Dificuldades enfrentadas no desenvolvimento da política de formação continuada nas IFES}

Na Tabela 12, observa-se que a grande dificuldade enfrentada pelo desenvolvimento de uma política de formação continuada nas IFES é a resistência do corpo docente a uma formação continuada. E está conjugada com outros elementos,

Tabela 11.1. Responsável pela definição das temáticas abordadas nas ações formativas as IFES que participaram do Cograd em 2014, que não a aplicaram, mas possuem estratégias.

\begin{tabular}{lcc}
\hline Informações institucionais & $\begin{array}{c}\text { Número de } \\
\text { IFES }\end{array}$ & Percentual \\
\hline $\begin{array}{l}\text { Órgão responsável pela execução da política ou sugestão } \\
\text { dos professores em formação }\end{array}$ & 3 & $37,50 \%$ \\
$\begin{array}{l}\text { Órgão responsável pela execução da política } \\
\begin{array}{l}\text { Órgão responsável pela execução da política; núcleos } \\
\text { estruturantes; ou sugestão dos professores em formação }\end{array}\end{array}$ & 1 & $12,50 \%$ \\
Ações dos coordenadores de cursos & 1 & $12,50 \%$ \\
Não responderam & 2 & $12,50 \%$ \\
Total & $\mathbf{8}$ & $\mathbf{1 0 0 \%}$ \\
\hline
\end{tabular}

Fonte: Elaborada pelos autores (2016). 
Tabela 12. Dificuldades enfrentadas no desenvolvimento da Política de Formação Continuada nas IFES que participaram do Cograd em 2014.

\begin{tabular}{|c|c|c|}
\hline Informações institucionais & $\begin{array}{l}\text { Número } \\
\text { de IFES }\end{array}$ & Percentual \\
\hline $\begin{array}{l}\text { Falta de formadores de professores universitários e resistência } \\
\text { de professores à formação pedagógica }\end{array}$ & 5 & $21,74 \%$ \\
\hline $\begin{array}{l}\text { Recursos financeiros; resistência de professores à formação } \\
\text { pedagógica; e outros }\end{array}$ & 3 & $13,04 \%$ \\
\hline $\begin{array}{l}\text { Apoio técnico-administrativo; falta de formadores de } \\
\text { professores universitários e resistência de professores à } \\
\text { formação pedagógica; e outros* }\end{array}$ & 2 & $8,70 \%$ \\
\hline $\begin{array}{l}\text { Recursos financeiros e resistência de professores à formação } \\
\text { pedagógica }\end{array}$ & 2 & $8,70 \%$ \\
\hline Resistência de professores à formação pedagógica & 2 & $8,70 \%$ \\
\hline $\begin{array}{l}\text { Falta de uma política nacional e institucional de incentivo } \\
\text { (pontuação para a carreira docente) }\end{array}$ & 2 & $8,70 \%$ \\
\hline Recursos financeiros & 2 & $8,70 \%$ \\
\hline Recursos financeiros e apoio técnico-administrativo & 1 & $4,35 \%$ \\
\hline $\begin{array}{l}\text { Recursos financeiros; apoio técnico-administrativo e resistência } \\
\text { de professores à formação pedagógica }\end{array}$ & 1 & $4,35 \%$ \\
\hline Recursos financeiros; apoio técnico-administrativo; e outros* & 1 & $4,35 \%$ \\
\hline $\begin{array}{l}\text { Recursos financeiros; resistência de professores à formação } \\
\text { pedagógica; e outros* }\end{array}$ & 1 & $4,35 \%$ \\
\hline Falta de formadores de professores universitários & 1 & $4,35 \%$ \\
\hline Total & 23 & $100 \%$ \\
\hline
\end{tabular}

* Falta de uma política nacional e institucional de incentivo (pontuação para a carreira docente) e compatibilidade de horário entre os docentes e disponibilidade. Fonte: Elaborada pelos autores (2016).

tais como, principalmente, a falta de formadores de professores universitários e de recursos financeiros.

A posição cética de alguns professores, em relação à sua formação continuada, vem ao encontro do que a Proposta de Organização do Ensino Fundamental (POEF), Balneário Camboriú (2002, p. 4), apresenta quando coloca que as pessoas envolvidas precisam estar atentas para não se deixarem contaminar por posturas conformistas, fechadas, avessas a transformações, atuando defensivamente em relação a mudanças.

Pimenta e Anastasiou (2005) também alertam que para que os saberes necessários ao professor se dirijam às situações de ensinar e com elas dialoguem, é necessário rever-se, redirecionar-se, ampliar-se e criar. O professor universitário não se prepara para ser docente, ele se prepara para ser pesquisador, uma vez que, historicamente, no Brasil, não existe uma preparação pedagógica para exercer a docência na universidade. 
Na Tabela 12.1, observa-se que, mesmo nas IFES que somente pensam sobre uma política de formação de professores, colocam-se as resistências dos professores em participar do programa como o maior dos problemas que poderiam enfrentar.

Cabe, ainda, um importante destaque, que foi uma citação realizada por várias pró-reitorias de graduação participantes do estudo, que a falta de uma política nacional e institucional de incentivo (pontuação para a carreira docente) e compatibilidade de horário entre os docentes e disponibilidade faz-se urgente para que este importante programa seja estabelecido como fundamental nas IFES em nosso País.

Fundamentamo-nos no conceito de desenvolvimento profissional de Garcia (1999), que dá destaque para o caráter processual desse desenvolvimento, trazendo, para isso, a ideia de evolução e continuidade em contraponto com aquela de que a formação dos professores nos cursos de graduação prepara para o desenvolvimento

Tabela 12.1. Dificuldades enfrentadas no desenvolvimento da Política de Formação Continuada nas IFES que participaram do Cograd em 2014, que não a aplicaram, mas possuem estratégias.

\begin{tabular}{lcc}
\hline Informações institucionais & $\begin{array}{c}\text { Número } \\
\text { de IFES }\end{array}$ & Percentual \\
\hline $\begin{array}{l}\text { Apoio técnico-administrativo e resistência de professores à } \\
\text { formação pedagógica }\end{array}$ & 1 & $12,50 \%$ \\
$\begin{array}{l}\text { Recursos financeiros; formadores de professores universitários; e } \\
\text { resistência de professores à formação pedagógica }\end{array}$ & 1 & $12,50 \%$ \\
$\begin{array}{l}\text { Recursos financeiros; falta de formadores de professores } \\
\text { universitários; apoio técnico-administrativo; e resistência de } \\
\text { professores à formação pedagógica }\end{array}$ & 1 & $12,50 \%$ \\
$\begin{array}{l}\text { Recursos financeiros; Falta de formadores de professores } \\
\text { universitários; apoio técnico-administrativo; resistência de } \\
\text { professores à formação pedagógica; e outros* }\end{array}$ & 1 & $12,50 \%$ \\
$\begin{array}{l}\text { Falta de formadores de professores universitários; resistência de } \\
\text { professores à formação pedagógica; e outros* }\end{array}$ & 1 & $12,50 \%$ \\
$\begin{array}{l}\text { Falta de formadores de professores universitários e outros* } \\
\text { Resistência de professores à formação pedagógica e outros* }\end{array}$ & 1 & $12,50 \%$ \\
Não respondeu & 1 & $12,50 \%$ \\
Total & 1 & $12,50 \%$ \\
\hline
\end{tabular}

* Falta de uma política nacional e institucional de incentivo (pontuação para a carreira docente) e metodologias de formação inadequadas às necessidades docentes.

Fonte: Elaborada pelos autores (2016). 
profissional. Conceber a formação contínua e permanente dos professores do ensino superior implica a compreensão que seus saberes profissionais sejam elaborados durante seu desenvolvimento profissional, ou seja, a preparação do professor não se esgota no momento da formação inicial nos cursos de graduação, nos cursos de licenciatura ou nos cursos de pós-graduação.

\subsection{Mecanismos de avaliação da política de formação continuada}

Na Tabela 13, observa-se que nem todas as IFES têm mecanismos de avaliação da política de formação continuada. Ainda $34,78 \%$ das IFES declaram que esses mecanismos não são utilizados.

Destacamos alguns mecanismos que as IFES utilizam para a avaliação da política de formação continuada:

Aplicação de formulários de avaliação das ações desenvolvidas(IFES3). Instrumentos elaborados pela comissão e aplicados ao final de cada curso (IFES 8).

Os participantes do programa respondem a um questionário de avaliação do programa (IFES 9).

Após cada atividade é distribuído um formulário de avaliação da atividade. Esta é tabulada e analisada (IFES 10).

Instrumento aplicado sempre que a formação ocorre para avaliação (IFES 14).

Instrumento de avaliação respondido pelos participantes ao final de cada ação formativa (IFES 15).

Há instrumentos para avaliar as ações realizadas que contribuem com esta avaliação (IFES 16).

Formulário de avaliação preenchido pelos participantes (IFES 21).

Tabela 13. Declaração quanto à existência de mecanismos de avaliação da política de formação continuada das IFES que participaram do Cograd em 2014.

\begin{tabular}{lcc}
\hline Mecanismos de avaliação & Número de IFES & Percentual (\%) \\
\hline Sim & 15 & $65,22 \%$ \\
Não & 8 & $34,78 \%$ \\
Total & $\mathbf{2 3}$ & $\mathbf{1 0 0 \%}$ \\
\hline
\end{tabular}

Fonte: Elaborada pelos autores (2016). 
Os próprios docentes avaliam as atividades por meio de formulários específicos (IFES 29).

[...] seminário de avaliação do próprio programa e suas ações, que são utilizadas como diretrizes para o planejamento das atividades do ano seguinte (IFES 30).

É curioso notar que nenhuma indicação para gerar mecanismos que as IFES utilizam para a avaliação da política de formação continuada considera o aluno (um dos autores principais do processo ensino e aprendizagem), perguntando a eles se, depois da participação do docente no curso, alguma coisa mudou, ou se a elaboração de questões melhorou, ou se a didática mudou. Consideramos ser necessário inserir os alunos nesse tipo de avaliação.

Na Tabela 13.1, somente uma instituição observa que pensa em mecanismos de avaliação da política de formação continuada.

Tabela 13.1. Declaração quanto à existência de mecanismos de avaliação da política de formação continuada das IFES que participaram do Cograd, em 2014, que não a aplicaram, mas possuem estratégias.

\begin{tabular}{lcc}
\hline Mecanismos de avaliação & Número de IFES & Percentual \\
\hline Sim & 1 & $12,50 \%$ \\
Não & 6 & $75,00 \%$ \\
Não respondeu & 1 & $12,50 \%$ \\
Total & $\mathbf{8}$ & $\mathbf{1 0 0} \%$
\end{tabular}

Fonte: Elaborada pelos autores (2016).

\subsection{Formas de socialização das experiências formativas nas IFES}

Na Tabela 14, observa-se que dentre as opções do instrumento de pesquisa, as instituições que têm uma política de formação continuada declaram que o principal item é a apresentação de práticas inovadoras (47,83\%).

Outro aspecto importante é que $17,39 \%$ das IFES ainda não têm definida a socialização das experiências formativas na instituição. 
Tabela 14. Formas de socialização das experiências formativas das IFES que participaram do Cograd em 2014.

\begin{tabular}{|c|c|c|}
\hline Formas de socialização das experiências formativas & $\begin{array}{l}\text { Número } \\
\text { de IFES }\end{array}$ & Percentual \\
\hline $\begin{array}{l}\text { Apresentação de práticas inovadoras; produção e } \\
\text { disponibilidade de materiais didáticos; e publicações de estudos } \\
\text { e reflexões sobre sua prática docente, decorrentes das ações } \\
\text { formativas vivenciadas. }\end{array}$ & 5 & $21,74 \%$ \\
\hline Apresentação de práticas inovadoras & 4 & $17,39 \%$ \\
\hline $\begin{array}{l}\text { Apresentação de práticas inovadoras; produção e } \\
\text { disponibilidade de materiais didáticos; publicações de estudos } \\
\text { e reflexões sobre sua prática docente, decorrentes das ações } \\
\text { formativas vivenciadas; e seminários, palestras, participação } \\
\text { em encontros universitários; criação de Fórum Permanente de } \\
\text { Discussão: Educação em Prosa. }\end{array}$ & 2 & $8,70 \%$ \\
\hline Relatos nas reuniões das comissões e relatórios e trabalhos eventuais & 2 & $8,70 \%$ \\
\hline Ainda não definido & 4 & $17,39 \%$ \\
\hline Outros* & 6 & $26,08 \%$ \\
\hline Total & 23 & $100 \%$ \\
\hline
\end{tabular}

* Combinações com somente uma indicação.

Fonte: Elaborada pelos autores (2016).

Uma das instituições, IFES 15, especifica o seguinte procedimento de socialização das experiências formativas:

São realizados estudos de caso, de acordo com o interesse dos grupos de professores sobre determinadas temáticas relativas à docência no ensino superior. Estes trabalhos subsidiam Núcleos Docentes Estruturantes, são socializados na ocasião do Planejamento (por solicitação de coordenadores de cursos), e em encontros nacionais e internacionais, sobre a formação de professores no ensino superior (IFES 15).

Na Tabela 14.1, observa-se que metade das IFES pensam desenvolver a socialização de práticas inovadoras. Ainda duas dessas IFES não apresentam nenhuma questão quanto a esse aspecto.

Importante enfatizar que formar profissionais é uma ação árdua devido à complexidade de conhecimento que eles devem obter, além da constante busca 
Tabela 14.1. Formas de socialização das experiências formativas das IFES que participaram do Cograd, em 2014, que não a aplicaram, mas possuem estratégias.

\begin{tabular}{lcc}
\hline Formas de socialização das experiências formativas & $\begin{array}{c}\text { Número } \\
\text { de IFES }\end{array}$ & Percentual \\
\hline Apresentação de práticas inovadoras & 3 & $37,50 \%$ \\
$\begin{array}{l}\text { Publicações de estudos e reflexões sobre sua prática docente, } \\
\text { decorrentes das ações formativas vivenciadas }\end{array}$ & 1 & $12,50 \%$ \\
$\begin{array}{l}\text { Apresentação de práticas inovadoras; produção e } \\
\text { disponibilidade de materiais didáticos; publicações de estudos } \\
\text { e reflexões sobre sua prática docente, decorrentes das ações }\end{array}$ & 1 & $12,50 \%$ \\
formativas vivenciadas; e recursos de EAD & & \\
Compartilhamento & 1 & $12,50 \%$ \\
Não responderam & 2 & $25,00 \%$ \\
Total & $\mathbf{8}$ & $\mathbf{1 0 0 \%}$ \\
\hline
\end{tabular}

Fonte: Elaborada pelos autores (2016).

de atualização e da necessidade do professor estar interagindo com seus pares, como troca de experiências, para que ocorra uma reflexão e compreensão de assuntos incertos, ou seja, a construção do processo de socialização profissional (ALBUQUERQUE, 2006).

Também é importante ressaltar que a reflexão sobre a experiência provoca o surgimento de possibilidades para que os docentes gerem conhecimento prático (GARCIA, 1999).

\subsection{Sugestões de políticas de formação continuada nas IFES}

Aos pró-reitores de graduação participantes do Cograd foram solicitadas sugestões para serem apresentadas como política de formação continuada dos docentes das IFES e que podem nortear a continuação das discussões. São elas:

A instituição de uma política nacional de incentivo à formação pedagógica articulada pelos órgãos de fomento (IFES 3).

Buscar incentivos programas para as IFES (IFES 5).

Instituir a política nacional e institucional de incentivo com mecanismos de avaliação dos resultados do trabalho acadêmico (IFES 8).

1) $\mathrm{O}$ Cograd deve recomendar à Andifes a implantação de programas de formação para a docência no Ensino Superior; 2) Encaminhar documento ao MEC sugerindo políticas de formação para a docência no Ensino Superior, acompanhadas de planos de financiamento (IFES 3). 1) Recurso com rubrica específica para esse fim;2) Que a instituição contratasse empresas terceirizadas para assuntos específicos; 3) 
Quando os docentes da instituição forem os ministrantes, deverão receber incentivo via bolsa ou hora capacitação; 4) professores em capacitação, receberão incentivos em dinheiro por hora de curso, pontuar na progressão funcional (IFES 10).

Pontuação no currículo para questões voltadas à produção para o ensino de Graduação (IFES 14).

A Cograd aponte para a SESU a necessidade de editais para subsidiar os programas institucionais (IFES 16).

Há necessidade de recursos disponíveis para a formação, bem como que o programa seja debatido junto a outras instâncias, inclusive com o sindicato. Outro ponto para que tais ações se tornem um Programa de Formação continuada implica investimento tecnológico e pessoal, benefícios (para que os professores possam, com o apoio das Unidades, se dedicar às formações promovidas, etc.) para os professores que investissem nessa formação coordenada pelo PDI. Todos esses processos somente serão passíveis de avaliação e mesmo da criação de mecanismos de avaliação, mediante um intenso diálogo com a comunidade docente e órgãos responsáveis (IFES 17).

[...] Iniciar o percurso formativo com uma aula inaugural: "Docência do Ensino Superior - sucessos do ofício", e neste momento buscarmos honrar nossos docentes aposentados relatando aos novatos e/ou colegas o valor de ser docente no Ensino Superior. Essa pequena ação tem restabelecido um vínculo com a profissão, com a comunidade acadêmica, um respeito às gerações que nos antecederam, enfim, possibilita relembrar o encantamento pela sala de aula, o que chamamos do "brilho no olhar", que é um dos componentes essenciais para nos mantermos docentes (IFES 18). . Induzir as IFES a assumirem esta responsabilidade (IFES 19).

Sistematizar as diversas experiências de formação continuada das IFES; socializar estas experiências em Seminário para que seja reelaborada, coletivamente, uma proposta de Política de Formação Continuada (IFES 22).

Edital próprio para as IFES buscarem recurso, mediante apresentação de projeto institucional, para promover a formação continuada de docentes das IFES (IFES 26).

1) Após sistematização e análise de dados coletados neste instrumento, que justificariam a proposta a ser apresentada, articulação junto ao MEC para pleitear garantia de recursos para implementação da política; 2) Que essa política fosse regulamentada mediante decreto presidencial, corrigindo lacuna da LDB 9394/1996 que não trata da necessidade de formação pedagógica para atuação de professores na Educação Superior; 
3) Ampla divulgação nas IFES, acerca do processo de negociação para implementação da política de formação docente (IFES 27).

É necessária a criação de uma política nacional de incentivo para a formação continuada do docente universitário, criando inclusive pontuação para este fim. O perfil exigido pela Capes e CNPq se afasta muito das ações de formação continuada para a graduação/docência, isso precisa ser revisto (IFES 28).

Uma proposta interessante seria considerar todos os aspectos profissionais que envolvem a carreira docente. Dessa maneira, poderiam ser abordados temas que permeassem não apenas as questões pedagógicas do processo ensino e aprendizagem, mas também da gestão da carreira acadêmica e todas as suas implicações, a valorização do ensino, da pesquisa e da extensão e as questões administrativas das instituições relacionadas ao governo federal (IFES 30).

Pontuação na carreira docente referente à formação continuada. Previsão explícita no orçamento das IFES de recursos para a formação continuada (IFES 31).

No Brasil, como podemos ver nesse estudo, a realidade ainda está distante de ser concretizada, mas já se percebe um movimento em direção a uma institucionalização das ações desenvolvidas no interior das IFES com o objetivo de promover o desenvolvimento profissional docente do professor universitário.

Destacamos Ramalho (2006), ao afirmar que o exercício da profissão docente requer uma sólida formação, não apenas nos conteúdos científicos próprios da disciplina, como também nos aspectos correspondentes a sua didática, ao encaminhamento das diversas variáveis que caracterizam a docência, sua preparação e constante atualização.

Portanto, percebem-se alguns indicativos de incentivos governamentais que podem impulsionar os programas de formação docente junto às IFES visando à manutenção da excelência na qualidade da oferta de cursos de graduação.

\section{Considerações finais}

Na pesquisa realizada ${ }^{4}$ sobre formação continuada e o atual contexto de ampliação e consciência do papel de responsabilidade no trabalho docente por parte do professor, verifica-se a tendência crescente de possibilidade de que a formação

\footnotetext{
4 Um grupo de trabalho intitulado Formação Docente foi desenvolvido junto ao Cograd no período de 2012 a 2014, culminando num Termo de Referência apresentado em marco de 2014 para a Andifes. O Grupo de Trabalho (GT) foi coordenado, no trabalho de coleta dos questionários e tabulação dos dados, pelo PróReitor de Ensino da Universidade Federal do Triângulo Mineiro - UFTM.
} 
continuada seja mais uma nova forma de regulação profissional do que rumo à promoção da profissionalização docente.

Para os professores já titulados, em todos os níveis de ensino, a formação continuada assume diferentes perspectivas: suprimento, atualização, treinamento, aprofundamento, pesquisa. Suprimento direcionado para formação complementar à inicial considerada, na maioria das vezes, precária. Marin (1996) e Martins (2009) já denunciavam as dificuldades históricas de formar bem os professores, o que exige a continuidade de cursos ao longo da carreira docente.

A profissão do professor, nos tempos atuais, está marcada por intensificação de quantificação de tarefas e uma complexidade cada vez maior. Hargreaves (1994), ao discorrer sobre o trabalho docente, expressa o "profissionalismo alargado". Alerta para a redução do tempo com a intensificação do processo de trabalho, o que acarreta falta de tempo para o aperfeiçoamento, criando uma sobrecarga crônica e persistente.

Tudo isso provoca redução na qualidade do ensino, especialmente, no caso dos professores, redução do tempo de preparação, condição fundamental para um bom ensino (HARGREAVES, 1994, p. 134-137).

Considerando os resultados da investigação realizada, há indicativos para as seguintes ações nas IFES: (1) institucionalização de programas de formação docente nas IFES com a criação de setores, coordenadorias com pessoas para pensarem e proporem projetos, ações e avaliação desses programas; (2) A definição de princípios de formação universitária nas IFES como, por exemplo, a valorização dos programas de monitoria e de tutoria, ampliando a compreensão da docência que vai para muito além do simples planejar e dominar técnicas ou metodologias de ensino.

Há, também, indicativos de incentivos governamentais ou políticas públicas que possam impulsionar os programas de formação docente junto às IFES, como:

Sugerir à Secretaria de Educação Superior (SESu) fomento financeiro por meio de edital ou disponibilização de recursos no orçamento anual para que as IFES implementem programas de formação continuada dos docentes. A SESu é a unidade do Ministério da Educação (MEC) responsável por planejar, orientar, coordenar e supervisionar o processo de formulação e implementação da Política Nacional de Educação Superior.

Junto à Coordenação de Aperfeiçoamento de Pessoal de Nível Superior (Capes), a indução à formação para a docência na Educação Superior nos cursos de 
pós-graduação para além do estágio em docência. A Capes é uma agência de fomento à pesquisa brasileira que atua na expansão e consolidação da pósgraduação stricto sensu (mestrado e doutorado) em todos os estados do país.

Junto ao Instituto Nacional de Estudos e Pesquisas Educacionais Anísio Teixeira (INEP), indicar a valorização, por meio dos indicadores de avaliação, das ações institucionais para desenvolvimento docente ou o desempenho dos docentes. O objetivo do INEP é promover estudos, pesquisas e avaliações periódicas sobre o sistema educacional brasileiro, com o objetivo de subsidiar a formulação e a implementação de políticas públicas para a área educacional.

E não menos importante, junto à Associação Nacional dos Dirigentes das Instituições Federais de Ensino Superior (Andifes), que representa oficialmente as IFES na interlocução com o governo federal, com as associações de professores, de técnicos-administrativos, de estudantes e com a sociedade em geral, indicar as seguintes ações: (1) lançamento de programas interinstitucionais de mobilidade docente incentivando e promovendo a troca de experiências entre instituições; (2) realização de seminário nacional para socialização de experiências exitosas desenvolvidas pelas IFES. 


\section{Professional development in the higher education of brazilian federal institutions context}

\section{Abstract}

The objective of this study was to identify which actions are developed by the Federal Institutions of Higher Education (IFES) in Brazil regarding continuing teacher education for Higher Education. For this, an instrument (questionnaire) was applied to collect information that sought to identify the existence of an institutional policy of continuing education for teachers in the Federal Institutions of Higher Education. To this end, a questionnaire was drafted by a group of professors in the ambit of the College of Graduating Pro-Rectors (COGRAD), which sought to identify the existence of an institutional policy of continuing education for its teachers. There is a growing trend that continuing education is a new form of professional regulation rather than promotion of teacher professionalization. Indications are given for continuing education actions, possible government incentives or public policies that can boost teacher training programs and that carry out dialogue with the federal government, teachers 'associations, technicaladministrative associations, students and society in general, indicating actions of a teacher professional development policy.

Keywords: Teacher education. Higher education. Federal institutions. Brazil.

\section{Formación del profesorado en el contexto de las instituciones de educación superior de Brasil}

\section{Resumen}

El objetivo de este estudio fue identificar cuáles son las medidas adoptadas por las Instituciones Federales de Enseñanza Superior - IFES en Brasil con respecto a la formación de docentes para la educación superior. Para ello se aplicó un instrumento (cuestionario) para recoger información que buscaba identificar la existencia de una politica institucional de formación de profesores en IFES. Una tendencia creciente que siguió la formación es más una nueva forma de regulación profesional para promover la profesionalización Se encontraron continuas acciones de educación por IFES, posibles incentivos de política gubernamental o pública que pueden impulsar programas de formación del profesorado en la IFES y sus vicerrectores sugieren que ANDIFES debe sostener diálogos con el gobierno federal, con las asociaciones de profesores, estudiantes técnicos y administrativos, y la sociedad en general, indicando acciones de una política de formación docente.

Palabras claves: Formación del profesorado. Educación superior. Instituciones Federales. Brasil. 


\section{Referências}

ALBUQUERQUE, M. O. de A. Formação continuada e o processo de socialização profissional. In: ENCONTRO DE PESQUISA EM EDUCAÇÃO DA UFPI, 4., 2006, Teresina. Anais eletrônicos... Teresina: UFPI, 2006. p. 1-14. Disponível em : <http://leg.ufpi.br/subsiteFiles/ppged/arquivos/files/ eventos/2006.gt2/GT2_2006_05.PDF>. Acesso em: 11 nov. 2015.

ALMEIDA, M. I. Desenvolvimento profissional docente: uma atribuição que também é do sindicato. In: REUNIÃO ANUAL DA ANPED, 23., 2000, Caxambu. Anais .... Caxambu: ANPED, 2000. p. 12-28.

ANASTASIOU, L. das G. C. Construindo a docência no ensino superior: relação entre saberes pedagógicos e saberes científicos. In: FELDMAN D.; ROSA, D. E. G.; SOUZA, V. C. (Org.). Didáticas e práticas de ensino: interfaces com diferentes saberes e lugares formativos. Rio de Janeiro: DP\&A, 2002. p. $173-187$.

ANDRÉ, M. et al. Estado da arte da formação de professores no Brasil. Educação \& Sociedade, Campinas; v. 20, n. 68, p. 301-309, dez. 1999.

BALNEÁRIO CAMBORIÚ. Secretaria Municipal de Educação. POEF Proposta de Organização do Ensino Fundamental: $5^{\circ}$ ao $8^{\circ}$ ano. Balneário Camboriú: PMBC, 2002.

BALZAN, N. C. Indissociabilidade de ensino-pesquisa como princípio metodológico. In: VEIGA, I. P. A; CASTANHO, M. E. L. M. (Org.). Pedagogia universitária: a aula em foco. Campinas, SP: Papirus, 2000. p. 115-136.

BRASIL. Lei n ${ }^{\circ} 10.861$, de 14 de abril de 2004. Institui o Sistema Nacional de Avaliação da Educação Superior - SINAES e dá outras providências. Diário Oficial [da República Federativa do Brasil], Brasília, DF, 15 abr. 2004. Disponível em: <http://www.planalto.gov.br/ccivil_03/_ato2004-2006/2004/ lei/110.861.htm>. Acesso em: 18 out. 2015.

CAMPOS, V. T. B. Docência no ensino superior brasileiro: representações de pós-graduandos de instituições federais de ensino superior. In: REUNIÃO ANUAL DA ANPED, 34., 2011, Natal. Anais eletrônicos... Natal, RN. GT 11 - Política de Educação Superior. Disponível em: <http://www.anped11.uerj. br/GT11-1133\%20int.pdf $>$. Acesso em: 10 fev. 2014. 
CUNHA, M. I. da. (Org.). Trajetórias e lugares de formação da docência universitária: da perspectiva individual ao espaço institucional. Araraquara, SP: Junqueira \& Marin, 2010.

CUNHA, M. I. da; ZANCHET, B. M. A. A problemática dos professores iniciantes: tendência e prática investigativa no espaço universitário. Educação, Porto Alegre, v. 33, n. 3, p. 189-197, set./dez. 2010. Disponível em: <http:// revistaseletronicas.pucrs.br/ojs/index.php/faced/article/viewFile/6999/5717>. Acesso em: 11 nov. 2015.

DALBERIO, O.; OLIVEIRA JÚNIOR, A. P. O desafio de ser e de atuar como docente universitário. EccoS - Rev. Cient., São Paulo, n. 26, p. 209-225, jul./dez. 2011.

DARLING-HAMMOND, L. et al. Professional learning in the learning profession: a status report on teacher development in the United States and abroad. Washington, DC: National Staff Development Council, 2009.

DAY, C. Formar docentes: Cómo, cuándo y en qué condiciones aprende el profesorado. Madrid: Narcea, 2005.

DEMO, P. Obsessão inovadora do conhecimento moderno. In:

Conhecimento Moderno: sobre ética e intervenção do conhecimento. Petrópolis, RJ: Vozes, 1997.

FIORENTINI, D.; CRECCI, V. M. Desenvolvimento profissional docente: um termo guarda-chuva ou um novo sentido à formação? Revista Brasileira de Pesquisa sobre Formação Docente, v. 5, n. 8, p. 11-23, jan./jun. 2013.

FULLAN, M.; HARGREAVES, A. A Escola como organização aprendente. 2. ed. Porto Alegre: Artmed, 2000.

GAETA, C.; PRATA-LINHARES, M. M. Formação de professores do ensino superior: experiências curriculares em cursos lato sensu. Olhar de professor, Ponta Grossa, v. 16, n. 2, p. 343-355, 2013. Disponível em: <http://www. revistas2.uepg.br/index.php/olhardeprofessor/article/view/6358/4421>. Acesso em: 11 nov. 2015.

GARCIA, C. M. Formação de professores para uma mudança educativa. Porto: Porto Editora, 1999.

HARGREAVES, A. Os professores em tempos de mudança: o trabalho e a cultura dos professores na idade pós-moderna. Lisboa: McGraw-Hill, 1994. 
LARROSA, J. Pedagogia Profana: danças, piruetas e mascaradas. Belo Horizonte: Autêntica, 1999.

MARIN, A. J. Propondo um novo paradigma para formar professores a partir das dificuldades e necessidades históricas nessa área. In: REALI, A. M. M. R.; MIZUKAMI, M. G. N. Formação de professores: tendências atuais. São Carlos: EdUFSCar, 1996. p. 59-91.

MARTINS, P. L. O. A didática e as contradições da prática. 3. ed. Campinas, SP: Papirus, 2009.

MASETTO, M. T. Docência na universidade. Campinas, SP: Papirus, 2002.

MOROSINI, M. C. Docência universitária e os desafios da realidade nacional. In: . (Org.). Professor do ensino superior: identidade, docência e formação. 2. ed. ampl. Brasília, DF: Plano Editora, 2001.

NEISLER, O. Higher Education Faculty Development Centers: Challenging disparities in the quality of classroom practice. In: Ono, Y (Ed.). Challenging disparities in education: $59^{\text {th }}$ International Yearbook on Teacher Education. Naruto: ICET, 2015. p. 77-83. Disponível em: <https://pt.scribd.com/ document/293644791/ICET2015-yearbook-Copy>. Acesso em: 09 nov. 2015.

NEVES, N. Conheça as diferenças entre os tipos de eventos antes de iniciar a organização. Manager Online. Barueri, [s.d.]. Disponível em: <http://www. manager.com.br/reportagem/reportagem.php?id_reportagem $=403>$. Acesso em: 11 NOV. 2015.

PAIVA, G. S. Recortes da formação docente da educação superior brasileira: aspectos pedagógicos, econômicos e cumprimento de requisitos legais. Ensaio: Avaliação e Políticas Públicas em Educação, v.18, n. 66, p.157-174, jan./mar. 2010.

PIMENTA, S. G.; ANASTASIOU, L. das G. C. Docência no ensino superior. São Paulo: Editora Cortez, 2005.

PONTE, J. P. Da formação ao desenvolvimento profissional. In: Actas do Profmat 98. Lisboa: Associação dos Professores de Matemática, 1998. p. 27-44. Disponível em: <http://www.educ.fc.ul.pt/docentes/jponte/docs-pt/98Ponte(Profmat).rtf $>$. Acesso em: 12 nov. 2015.

RAMALHO, B. L. Reflexões sobre o ensino e o exercício da docência no ensino superior. ForGRAD em Revista, Vitória, n. 1, p. 26-32, 2006. 
RIOS, T. A. Competência ou competências: o novo e o original na formação de professores. In: ROSA, D. E. G.; SOUZA, V. C. (Org.). Didática e práticas de ensino: interfaces com diferentes saberes e lugares formativos. Rio de Janeiro: DP\&A, 2002. p. 157-172.

SOWDER, J. T. The Mathematical Education and Development of Teachers. In: LESTER, F. K. (Ed.). Second handbook of research on mathematics teaching and learning: A Project of the National Council of Teachers of Mathematics. North Carolina: Information Age Publishers, 2007. p. 157-223.

ZANETTI, E. Workshops, oficinas, seminários e convenções qual a diferença? Blog do Eloi Zanetti. 25 jul. 2012. Disponível em $<$ http://www.eloizanetti. com.br/blog/2012/07/workshops-oficinas-seminarios-e-convencoes-qual-adiferenca/>. Acesso em: 16 nov. 2015.

\section{Informações dos autores}

Ailton Paulo de Oliveira Júnior: Doutor e Pós-Doutor em Educação pela Universidade de São Paulo (USP). Professor Associado do Centro de Matemática, Computação e Cognição e do Programa de Pós-Graduação em Ensino, História e Filosofia das Ciências e Matemática na Universidade Federal do ABC. Contato: drapoj@uol.com.br

Martha Maria Prata-Linhares: Doutora em Educação pela Pontifícia Universidade Católica de São Paulo (PUC-SP). Professora do Programa de Pós-Graduação em Educação e do Departamento de Educação em Ciências, Matemática e Tecnologias na Universidade Federal do Triângulo Mineiro. Contato: martha.prata@gmail.com

Acir Mário Karwoski: Doutor em Letras pela Universidade Federal do Paraná (UFPR). Pós-Doutorado em Educação (UCSB-USA). Professor Associado do Departamento de Linguística e Língua Portuguesa e do Programa de Pós-Graduação em Educação na Universidade Federal do Triângulo Mineiro. Contato: acirmario@gmail.com 


\section{ANEXO I}

\section{Instrumento (Questionário) de coleta de dados}

1. Existe uma política institucional de formação continuada para os docentes?

( ) Sim. Há quanto tempo?

( ) Não. O que se pretende?

2. Qual o público-alvo?

( ) Docentes em estágio probatório.

( ) Docentes efetivos, independentemente do tempo de serviço.

( ) Docentes substitutos/temporários.

2.1. Faça observações sobre o público-alvo.

3. Quais os órgãos responsáveis pela execução da política?

( ) Administração Superior. Especificar:

( ) Unidades Acadêmicas. Especificar:

4. Há uma definição de periodicidade para as atividades de formação do público-alvo?

( ) Sim. Especificar:

( ) Não.

5. Qual é a natureza das atividades formativas?

( ) Formação

( ) Desenvolvimento

( ) Atualização

( ) Outros. Especificar:

6. Quais as ações formativas oferecidas e as respectivas cargas horárias?

( ) Cursos

( ) Oficinas

( ) Seminários

( ) Outros. Especificar: 
7. Existe recurso orçamentário destinado a essa política institucional de formação continuada?

( ) Sim.

( ) Não.

8. Existe algum tipo de incentivo institucional para o docente que participa da formação continuada?

( ) Sim. Especificar:

( ) Não.

9. As informações institucionais (relatórios, CPA etc.) são utilizadas na definição da política de formação continuada?

( ) Sim. Especificar:

( ) Não.

10. Como são definidas as temáticas nas ações formativas?

( ) Órgão responsável pela execução política. Especificar:

( ) Comitê assessor específico.

( ) Núcleos estruturantes.

( ) Sugestão dos professores em formação.

( ) Outros. Especificar:

11. Quais são as dificuldades enfrentadas no desenvolvimento da política de formação continuada?

( ) Recursos financeiros.

( ) Formadores de professores universitários (perfil, disposição, disponibilidade).

( ) Apoio técnico-administrativo.

( ) Resistência de professores à formação pedagógica.

( ) Outros. Especificar:

12. Existem mecanismos de avaliação da política de formação continuada?

( ) Sim. Especificar:

( ) Não. 
12.1 Qual seria a sugestão para o Cograd apresentar proposta de política de formação continuada dos docentes das IFES?

13. Quais as formas de socialização das experiências formativas na sua IFES?

( ) Apresentação de práticas inovadoras.

( ) Produção e disponibilização de materiais didáticos.

( ) Publicações de estudos e reflexões sobre a prática docente, decorrentes das ações formativas vivenciadas.

( ) Outros. Especificar: 